\title{
Characteristics of necrotoxigenic Escherichia coli isolated from septicemic and diarrheic calves between 1958 and 1970
}

\author{
Sigrid Van Bost*, Marie-Hélène Bâbe, \\ Etienne Jacquemin, Jacques Mainil \\ Laboratory of Bacteriology, Faculty of Veterinary Medicine, University of Liège, \\ Sart-Tilman B43a, 20 bd de Colonster, B-4000 Liège, Belgium
}

Received 30 October 2000; received in revised form 19 April 2001; accepted 30 April 2001

\begin{abstract}
A total of 434 Escherichia coli isolated from septicemic calves between 1958 and 1965 and 430 E. coli isolated from diarrheic calves between 1967 and 1970 were studied by colony hybridisation and PCR assays for the presence of the cnfl-and the cnf2-like genes. They were also studied for the presence of genes coding for putative virulence factors associated with the CNF toxins including F17-, Pap- and Sfa-fimbrial adhesins and the recently described CDT-III toxin and AfaVIII-afimbrial adhesin. Thirty (7\%) of the 434 septicemic strains were positive for CNF by colony hybridisation. Twenty-six were confirmed as necrotoxigenic E. coli type 2 (NTEC2) and four as NTEC1 by PCR. Thirty-five $(8 \%)$ of the 430 diarrheic strains were positive for CNF by colony hybridisation. Five of them were studied by PCR and confirmed as NTEC1. The 26 septicemic NTEC 2 strains and 20 of the 35 diarrheic NTEC including three of the five NTEC1 were positive for CDT-III. All adhesins studied were present in NTEC as well as in non-NTEC. NTEC1 were mainly Pap-, Sfa- and/or Afa8-positive, whereas NTEC2 were mainly F17- and/or Afa8-positive. This study shows that necrotoxigenic $E$. coli with their associated adhesins and toxins were present in calves as early as 1958, but their prevalence seems to have increased since that time. (C) 2001 Elsevier Science B.V. All rights reserved.
\end{abstract}

Keywords: Escherichia coli; Necrotoxigenicity; Cattle-bacteria

\section{Introduction}

Necrotoxigenic Escherichia coli are an emerging category of pathogenic bacteria. They are defined on the basis of production of a toxin called cytotoxic necrotising factor (CNF)

\footnotetext{
* Corresponding author. Tel.: +32-4-366-40-62; fax: +32-4-366-41-22.

E-mail address: svanbost@ulg.ac.be (S. Van Bost).
} 
(Caprioli et al., 1983). This toxin was named CNF for its capacity to induce cell multinucleation in Vero and HeLa tissue culture and to cause necrosis in rabbit skin (De Rycke et al., 1990). Two different types of NTEC have been reported: NTEC1 and NTEC2 (De Rycke et al., 1987, 1990). NTEC1 strains have been isolated from cases of enteritis in ruminants, pigs, dogs, rabbits and horses and from extra-intestinal infections in pigs, dogs, cats and humans (De Rycke et al., 1999). NTEC2 strains have been mainly isolated from ruminants with intestinal infections or with septicemia (Blanco et al., 1996; Cid et al., 1996; Pohl et al., 1997). The necrotoxigenic E. coli produce two different toxins (CNF1 and CNF2) closely related antigenically and genetically (De Rycke et al., 1987; Oswald et al., 1994a).

In 1989, Oswald and collaborators identified CNF2 as the Vir toxin of E. coli harbouring the Vir plasmid (Smith, 1974). The cnf2 gene is indeed carried by the Vir plasmid (Oswald et al., 1994a), whereas the cnfl gene is located on the chromosome (Falbo et al., 1992).

Genes located on the Vir plasmid encode other putative virulence factors. The family of the F17 fimbriae, produced by E. coli isolated from animals and human beings with septicemia and/or diarrhea (Le Bouguenec and Bertin, 1999), include several antigenic subtypes: F17a, F17b, F17c and F17d. The F17b fimbrial subtype was identified as the Vir adhesin which is coded by genes located on the Vir plasmid as can the F17c fimbrial subtype (Oswald et al., 1991; El Mazouari et al., 1994; Mainil et al., 1997, 2000). A new member of the afimbrial adhesin AfaVIII, was recently identified in E. coli from cattle (Mainil et al., 1997; Lalioui et al., 1999). The afa-8 gene cluster was demonstrated to be also located on the Vir plasmid in NTEC2 and chromosome-located in other E. coli including NTEC1 (Mainil et al., 1997; Gérardin et al., 2000). Finally, a member of the cytolethal distending toxins, CDT-III (Pérès et al., 1997) produced by NTEC2 is coded by genes located on the Vir plasmid.

On the other hand, most of the NTEC1 isolates harbour sequences typical of the Pfimbrial adhesin family and either one S-fimbrial (Sfa or F1C) (Fournout et al., 2000) or the AfaVIII-afimbrial adhesins (Mainil et al., 1997, 1999; Lalioui et al., 1999; Gérardin et al., 2000), which are all located on the chromosome. The pap/prs gene clusters coding for Pfimbriae and the cnfl gene are actually associated with a hly operon coding for the $\alpha$ hemolysin, forming the so-called pathogenicity island 5 or Pai 5 (Blum et al., 1995; De Rycke et al., 1999; Dozois and Curtiss III, 1999).

The purpose of the present work was to determine the prevalence of NTEC1 and NTEC2 among E. coli isolated from diseased calves before their description by Smith (1974) as well as their other putative virulence factors. This was performed by hybridising collections of invasive and intestinal E. coli from the 1950s and 1960s with gene probes for the different adhesins and toxins described here above.

\section{Materials and methods}

\subsection{E. coli strains}

All E. coli strains used in this study originated from the collections of the Laboratory of Bacteriology, Faculty of Veterinary Medicine, University of Liège. 
A total of 434 strains were isolated from heart blood or internal organs of septicemic calves. They were collected in Belgium between 1958 and 1965 (Kaeckenbeeck and Thomas, 1960) and preserved in a freeze-dried form.

A total of 430 strains were isolated from faeces of diarrheic calves. They were collected in Belgium between 1967 and 1970 (Schoenaers and Kaeckenbeeck, 1973) and preserved in agar deeps. In 1987, they were transferred onto Whatman 541 paper filters (Whatman International Ltd., Maidstone, England) (Mainil et al., 1990).

Five E. coli strains were used as positive or negative controls: S5 (CNF2+, CDTIII+, F17+); A30 (AfaIII+); J96 (CNF1+, Pap+, Sfa+); 239KH89 (CNF1+, AfaVIII+) and HS (negative control).

\subsection{Serogroups}

The serogroups of the septicemic strains were determined at the time of isolation using antisera to somatic antigens O (O1-O142) (Kaeckenbeeck and Thomas, 1960).

\subsection{Gene probes}

Six gene probes were used. The CNF probe was derived by a Pst $1+$ Cla1 restriction of the pEOSWO1 plasmid. The $335 \mathrm{bp}$ fragment hybridises with both CNF1- and CNF2-producing strains (Oswald et al., 1994b). The other five probes were derived by PCR as described in the Section 2.5. The Sfa probe was derived from the strain 536, it corresponds to the $s f a D$ and $s f a E$ genes (Le Bouguenec et al., 1992). The Pap probe was derived from the strain $\mathrm{C} 1212$ and consists of a fragment internal to the papC gene (Le Bouguenec et al., 1992). The F17 probe was derived from the strain 25KH09 and corresponds to the major subunit $f 17 a$ (Lintermans et al., 1988; Bertin et al., 1996). Those three probes are family probes. The Afa probe was derived from the strain 239 KH 89 and consists of an internal fragment of the afaE gene of the $a f a-8$ gene cluster (Lalioui et al., 1999). This probe is specific for AfaVIII. The CDT probe, which was derived from the $c d t I I I$ genes of the NTEC2 strain 1404 (Pérès et al., 1997) with specific primers (GAA AAT AAA TGG AAT ATA AAT GTC CG and TTT GTG TCG GTG CAG CAG GGA AAA), cross-hybridises with the cdtII genes (Oswald, personal communication).

\subsection{DNA colony hybridisations}

Septicemic E. coli were grown overnight at $37^{\circ} \mathrm{C}$ in Luria-Bertani broth (neutralised peptone $10 \mathrm{~g} / \mathrm{l}$; yeast extract $5 \mathrm{~g} / \mathrm{l} ; \mathrm{NaCl} 10 \mathrm{~g} / \mathrm{l} ; \mathrm{pH}$ 7.5) and subsequently overnight on Gassner-agar medium (Merck, Darmstad, Germany). They were transferred onto Whatman paper filters, which were prepared as previously described (Mainil et al., 1990). The filters with fecal E. coli were prepared in 1987 (Mainil et al., 1990).

All those filters were hybridised overnight at $65^{\circ} \mathrm{C}$ with each probe (Mainil et al., 1990). After washing, they were autoradiographed for 1-7 days. 


\subsection{PCR assays for cnfl and cnf2}

Bacteria were incubated in Luria-Bertani broth at $37^{\circ} \mathrm{C}$ overnight. $300 \mu \mathrm{l}$ were centrifuged at $13,000 \mathrm{rpm}$ for $30 \mathrm{~s}$. The pellet was suspended in $50 \mu \mathrm{l}$ of sterile water, incubated at $100^{\circ} \mathrm{C}$ for $10 \mathrm{~min}$ and centrifuged. The supernatant was used in the PCR reaction. Each microtube (Eppendorf, Hamburg, Germany) contained 1 IU of Taq DNA Polymerase; $5 \mu \mathrm{l}$ of PCR Nucleotide Mix $10 \mathrm{mM} ; 5 \mu \mathrm{l}$ of Taq DNA Polymerase Buffer 10X; $0.5 \mu \mathrm{l}$ of each primer $(40 \mathrm{nM})$ and $5 \mu \mathrm{l}$ of DNA. The reaction mixture was overlaid with mineral oil (Nujol Mineral Oil, Perkin-Elmer, Branchlung, NJ, USA). The PCR was performed with a thermal cycler (Perkin-Elmer Cetus, Branchlung, NJ, USA) at $94^{\circ} \mathrm{C}$ for $10 \mathrm{~min}$ followed by 25 cycles of $94^{\circ} \mathrm{C}$ for $1 \mathrm{~min}, 60^{\circ} \mathrm{C}$ for $1 \mathrm{~min}$ and $72^{\circ} \mathrm{C}$ for $1 \mathrm{~min}$. The amplified product was visualised by gel electrophoresis using $10 \mu \mathrm{l}$ of the final reaction mixture on a $2 \%$ agarose (Life Science Internationals, Zelik, Belgium) gel in TAE buffer (40 mM Tris, $20 \mathrm{mM}$ acetic acid, and $2 \mathrm{mM}$ EDTA $\mathrm{pH}$ 8.3). The samples were electrophorised for $60 \mathrm{~min}$ at $70 \mathrm{~V}$. Amplified DNA fragments were located by UV fluorescence after staining with ethidium bromide.

A $0.75 \mathrm{~kb}$ band is amplified with both CNF2- and CNF1-producing strains (primers TTA TAT AGT CGT CAA GAT GGA and CAC TAA GCT TTA CAA TAT TGA) and a $1.25 \mathrm{~kb}$ band is amplified only with CNF2-producing strains (primers TAT CAT ACG GCA GGA GGA AGC ACC and GTC ACA ATA GAC AAT AAT TTT CCG). Therefore, a positive response with both pairs of primers is associated with CNF2-producing strains whereas a positive response only with the $0.75 \mathrm{~kb}$ band is associated with CNF1-producing strains (Oswald, personal communication).

\section{Results}

\subsection{Toxin probes}

Out of 434 septicemic strains, 30 (7\%) hybridised with the CNF probe. Twenty-six strains were identified as NTEC2 by the PCR assay and four were identified as NTEC1. The 26 NTEC2 strains hybridised with the CDT-III probe. All the remaining strains (NTEC1 or non-NTEC) were negative with this probe (Table 1).

Table 1

Colony hybridisation results among the septicemic strains

\begin{tabular}{lclrrrr}
\hline E. coli & $\begin{array}{l}\text { Total number } \\
\text { of strains }\end{array}$ & \multicolumn{4}{l}{ Number of positive strains with the probes } & \\
\cline { 3 - 6 } & & CDT & F17 & AfaVIII & Pap & Sfa \\
\hline NTEC2 & 26 & $26(100 \%)$ & $18(69 \%)$ & $18(69 \%)$ & $2(7 \%)$ & $5(19 \%)$ \\
NTEC1 & 4 & 0 & $1(25 \%)$ & $3(75 \%)$ & $4(100 \%)$ & $4(100 \%)$ \\
Non-NTEC & 404 & 0 & $225(56 \%)$ & $211(51 \%)$ & $105(26 \%)$ & $15(4 \%)$ \\
Total & 434 & 26 & 244 & 232 & 111 & 24 \\
\hline
\end{tabular}


Table 2

Colony hybridisation results among the diarrheic strains

\begin{tabular}{lclrrrr}
\hline E. coli & $\begin{array}{l}\text { Total number } \\
\text { of strains }\end{array}$ & \multicolumn{4}{l}{ Number of positive strains with the probes } & \\
\cline { 3 - 7 } & & CDT & F17 & AfaVIII & Pap & Sfa \\
\hline NTEC (1 and 2) & 35 & $20(57 \%)$ & $11(31 \%)$ & $22(62 \%)$ & $15(43 \%)$ & $3(8 \%)$ \\
NTEC1 $^{\text {a }}$ & 5 & $2(40 \%)$ & $3(60 \%)$ & $3(60 \%)$ & $3(60 \%)$ & 0 \\
Non-NTEC & 395 & 0 & $72(18 \%)$ & $86(21 \%)$ & $62(16 \%)$ & $5(1 \%)$ \\
Total & 430 & 20 & 83 & 108 & 77 & 8 \\
\hline
\end{tabular}

a Only five strains could be recovered and PCR identified as NTEC1.

Out of 430 diarrheic strains, 35 (8\%) hybridised with the CNF probe. Unfortunately, only five of them were recovered from the agar deeps. They were identified by PCR as NTEC1. Twenty strains hybridised with the CDT-III probe (Table 2). All of them were CNF-positive strains and two of them were among the five strains confirmed as NTEC1 by PCR.

\subsection{Serogroups}

Fourteen serogroups were recognised among the 30 septicemic NTEC strains (Table 3). The most common among the 26 NTEC2 strains were O78 (23\%) and O15 (15\%). The serogroups of three of the four NTEC1 were O18, O23 and O117. Five NTEC2 and one NTEC1 were not typeable with the antisera used (Kaeckenbeeck and Thomas, 1960).

Table 3

O serogroups of septicemic strains

\begin{tabular}{|c|c|c|}
\hline O serogroup ${ }^{a}$ & NTEC $1^{b}$ & $\mathrm{NTEC}^{\mathrm{b}}$ \\
\hline $\mathrm{O} 2$ & - & 1 \\
\hline O15 & - & 4 \\
\hline O18 & 1 & - \\
\hline $\mathrm{O} 23$ & 1 & - \\
\hline O45 & - & 1 \\
\hline O55 & - & 1 \\
\hline O63 & - & 2 \\
\hline O78 & - & 6 \\
\hline O86 & - & 1 \\
\hline O88 & - & 1 \\
\hline O103 & - & 1 \\
\hline O117 & 1 & 1 \\
\hline O132 & - & 1 \\
\hline O140 & - & 1 \\
\hline $\mathrm{NT}^{\mathrm{c}}$ & 1 & 5 \\
\hline
\end{tabular}

${ }^{a}$ From Kaeckenbeeck and Thomas (1960).

${ }^{\mathrm{b}}$ Number of strains with the serogroup.

${ }^{\mathrm{c}}$ Not typeable with the antisera used. 


\subsection{Hybridisation of NTEC strains with adhesin probes}

\subsubsection{Septicemic strains}

All four NTEC1 and 25 NTEC2 tested positive with at least one of these probes (Table 1). All NTEC1 were Pap $+\mathrm{Sfa}+$ and three were AfaVIII + also. The 25 NTEC2 were F17+ (seven strains), AfaVIII+ (seven strains) or F17+ AfaVIII+ (11 strains); six of them being also $\mathrm{Sfa}+$ and/or Pap + .

\subsubsection{Diarrheic strains}

Only 29 out of the 35 fecal NTEC tested positive with at least one adhesin probe (Table 2). Gene hybridisation profiles were typical of NTEC2: F17+ and/or AfaVIII+ (14 strains) or of NTEC1 (including the five strains PCR identified as NTEC1): Pap + and $\mathrm{Sfa}+$ or AfaVIII+ (10 strains). A few atypical results were observed: F17+ Pap + (two strains); F17 + AfaVIII + Pap + (two strains) F17 + AfaVIII + Pap + Sfa + (one strain) (Table 4).

\subsection{Hybridisation of non-NTEC strains with adhesin probes}

Many non-NTEC strains also tested positive with the adhesin probes (Tables 1 and 2). Of the septicemic strains, a majority was positive with the F17 probe $(56 \%)$ followed by the AfaVIII probe (51\%) and the Pap probe $(26 \%)$. Only a minority hybridised with the Sfa probe $(4 \%)$ (Table 1). The most prevalent pathotypes were

Table 4

Pathotypes of the isolates

\begin{tabular}{|c|c|c|c|c|}
\hline \multirow[t]{2}{*}{ Pathotypes } & \multicolumn{2}{|c|}{ Septicemic strains ${ }^{\mathrm{a}}$} & \multicolumn{2}{|c|}{ Diarrheic strains ${ }^{\mathrm{a}}$} \\
\hline & NTEC $^{\mathrm{b}}$ & Non-NTEC & NTEC $^{\mathrm{c}}$ & Non-NTEC \\
\hline F17 & 7 & 27 & 3 & 55 \\
\hline AfaVIII & 6 & 31 & 7 & 32 \\
\hline Pap & - & 19 & - & 22 \\
\hline Sfa & - & 5 & - & - \\
\hline F17/AfaVIII & 6 & 117 & 4 & 19 \\
\hline F17/Pap & - & 32 & 2 & 6 \\
\hline F17/Sfa & - & - & - & - \\
\hline AfaVIII/Pap & - & 4 & 7 & 14 \\
\hline AfaVIII/Sfa & 1 & 9 & 1 & 1 \\
\hline Pap/Sfa & 1 & - & 2 & - \\
\hline F17/AfaVIII/Pap & 1 & 49 & 2 & 8 \\
\hline F17/AfaVIII/Sfa & 3 & - & - & - \\
\hline AfaVIII/Pap/Sfa & 2 & 1 & - & 1 \\
\hline F17/AfaVIII/Pap/Sfa & 2 & - & 1 & - \\
\hline Total number & 30 & 404 & 35 & 395 \\
\hline
\end{tabular}

\footnotetext{
${ }^{a}$ Number of strains with the pathotype.

b 4 NTEC1 and 26 NTEC 2.

c Only five of them could be PCR identified as NTEC1.
} 
$\mathrm{F} 17+\mathrm{AfaVIII}+$ and F17 + AfaVIII + Pap + . The others were present in $<10 \%$ of the strains (Table 4).

The same probes were hybridised by the diarrheic strains, but in lesser proportion: AfaVIII (21\%), F17 (18\%), Pap (16\%), and Sfa (1\%). The most prevalent pathotype was $\mathrm{F} 17+$. The other pathotypes were present in $<10 \%$ of the strains (Table 4 ).

\section{Discussion}

The cytotoxic necrotising factors (CNF) 1 and 2 were described, respectively in 1983 (Caprioli et al., 1983) and in 1974 (Smith, 1974; Oswald et al., 1989). Actually, Necrotoxigenic E. coli (NTEC) are considered as emerging pathogens (De Rycke et al., 1999). Using genetic tools, we were however, able to show that 7-8\% of invasive and fecal E. coli isolated from diseased calves between 1958 and 1970 are NTEC strains. Most of the invasive NTEC are NTEC2 (26 strains of 30), but only five out of the 35 fecal NTEC were recovered and identified as NTEC1.

Nevertheless, the proportions of NTEC strains reported in more recent studies (Burns et al., 1996; Pohl et al., 1997; reviewed in De Rycke et al., 1999) are much higher. These differences can be explained by (a) the type of the animal populations sampled as for instance the risk of NTEC infection increases after the first month of life (Orden et al., 1999); or (b) the changes throughout the years in animal husbandry as intensive rearing, which can favour the dissemination of bacterial pathogens, has increased since the early 1960s; or (c) the decrease of incidence of other pathogens because of husbandry and vaccinal prophylaxis as for enterotoxigenic E. coli; or (d) the selection of resistant clones and/or plasmids by extensive antibiotic use; or (e) an increased awareness and the apparition of better laboratory techniques.

Only the serogroups of invasive E. coli were determined. The O serogroups recognised vary, but the most frequently observed were $\mathrm{O} 78$ and $\mathrm{O} 15$; which are indeed frequently associated with bovine NTEC2 strains (Burns et al., 1996; Mainil et al., 1999). On the other hand, serogroups observed among NTEC1 are not common (De Rycke et al., 1999; Mainil et al., 1999).

Not only did the cnfl and cnf2 genes exist before 1983 and 1974, but DNA sequences related to genes coding for the other putative virulence factors of NTEC were also already present: $f 17$ described in ovine and bovine E. coli by Smith (1974) as Vir adhesin and redescribed later under the name F17b (El Mazouari et al., 1994); pap/prs and sfalfoc described in human uropathogenic E. coli in 1980 and 1986, respectively (Johnson, 1991) and for the first time in bovine E. coli in early 1990s (Blanco et al., 1990; Harel et al., 1991); $c d t$-III described in 1997 (Pérès et al., 1997); and most recently afa-8 (Lalioui et al., 1999).

These DNA sequences, were thus, present in invasive and fecal NTEC and non-NTEC, but were much more frequent among the septicemic strains, emphasising their potential role in extra-intestinal rather than intestinal pathologies. Most NTEC1 and many NTEC2 actually harbour several other properties of invasive E. coli (De Rycke et al., 1999; Mainil et al., 1999).

NTEC strains and their putative virulence factors, thus, existed prior to their published description. The difference observed resides in their frequency. 


\section{Acknowledgements}

This work was supported by a grant from the Ministère des Classes Moyennes et de l'Agriculture, Recherche et développement - convention 5936 (2000-2002).

We thank E. Oswald from the Laboratoire de Microbiologie Moléculaire Associé of the Institut National de Recherche Agronomique for the CDT and CNF primers and A. Kaeckenbeeck honorary professor from the Department of Bacteriology, Faculty of Veterinary Medicine, University of Liège for providing and serotyping the septicemic strains.

\section{References}

Bertin, Y., Martin, C., Oswald, E., Girardeau, J.-P., 1996. Rapid and specific detection of F17-related pilin and adhesin genes in diarrheic and septicemic Escherichia coli strains by multiplex PCR. J. Clin. Microbiol. 34, 2921-2928.

Blanco, J., Alonzo, M., Gonzales, E., Blanco, M., Garabal, J., 1990. Virulence factors of bacteraemic Escherichia coli with particular reference to production of cytotoxic necrotising factor (CNF) by P-fimbriate strains. J. Med. Microbiol. 31, 175-183.

Blanco, J., Cid, D., Blanco, J.E., Blanco, M., Ruiz Santa Quiteiria, J.A., de la Fuente, R., 1996. Serogroups, toxins and antibiotic resistance of Escherichia coli strains isolated from diarrhoeic lambs in Spain. Vet. Microbiol. 49, 209-217.

Blum, G., Falbo, V., Caprioli, A., Hacker, J., 1995. Gene clusters encoding the cytotoxic necrotising factor type 1 , Prs-fimbriae and $\alpha$-hemolysin form the pathogenicity island II of the uropathogenic Escherichia coli strain J96. FEMS Microbiol. Lett. 126, 189-196.

Burns, A., Ball, H., Finlay, D., 1996. CNF producing Escherichia coli isolated from cattle in Northern Ireland. Vet. Microbiol. 49, 235-241.

Caprioli, A., Falbo, V., Roda, L., Ruggeri, F., Zona, C., 1983. Partial purification and characterisation of an Escherichia coli toxic factor that induces morphological cell alterations. Infect. Immunol. 39, 1300-1306.

Cid, D., Blanco, M., Blanco, J.E., Ruiz Santa Quiteiria, J.A., de la Fuente, R., Blanco, J., 1996. Serogroups, toxins and antibiotic resistance of Escherichia coli strains isolated from diarrhoeic goat kids in Spain. Vet. Microbiol. 53, 349-353.

De Rycke, J., Guillot, J., Boivin, R., 1987. Cytotoxins in non-enterotoxigenic strains of Escherichia coli isolated from feces of diarrheic calves. Vet. Microbiol. 15, 137-150.

De Rycke, J., Gonzales, E., Blanco, J., Oswald, E., Blanco, M., Boivin, R., 1990. Evidence for two types of cytotoxic necrotising factor in human and animal clinical isolates of Escherichia coli. J. Clin. Microbiol. 28, 694-699.

De Rycke, J., Milon, A., Oswald, E., 1999. Necrotoxic Escherichia coli (NTEC): two emerging categories of human and animal pathogens. Vet. Res. 30, 221-233.

Dozois, C., Curtiss III, R., 1999. Pathogenic diversity of Escherichia coli and the emergence of exotic islands in the gene stream. Vet. Res. 30, 157-159.

El Mazouari, K., Oswald, E., Hernalsteens, J.-P., Lintermans, P., De Greve, H., 1994. F17-like fimbriae from an invasive Escherichia coli strain producing cytotoxic necrotising factor type 2 toxin. Infect. Immunol. 62 , 2633-2638.

Falbo, V., Famiglietti, M., Caprioli, A., 1992. Gene block encoding production of cytotoxic necrotising factor 1 and hemolysin in Escherichia coli isolates from extraintestinal infections. Infect. Immunol. 60, 2182-2187.

Fournout, S., Dozois, C., Odin, M., Desautels, C., Pérès, S., Hérault, F., Daigle, F., Segafredo, C., Laffitte, J., Oswald, E., Fairbrother, J.M., Oswald, I., 2000. Lack of a role of cytotoxic necrotising factor 1 toxin from 
Escherichia coli in bacterial pathogenicity and host cytokine response in infected germ-free piglets. Infect. Immunol. 68, 839-847.

Gérardin, J., Lalioui, L., Jacquemin, E., Le Bouguénec, C., Mainil, J., 2000. The afa-related gene cluster in necrotoxigenic and other Escherichia coli from animals belongs to the afa-8 variant. Vet. Microbiol. 76, $175-184$.

Harel, J., Daigle, F., Maiti, S., Desautels, C., Labigne, A., Fairbrother, J.M., 1991. Occurrence of pap-, sfa-, and afa-related sequences among F165-positive Escherichia coli from diseased animals. FEMS Microbiol. Lett. $82,177-182$.

Johnson, J.R., 1991. Virulence factors in Escherichia coli urinary tract infection. Clin. Microbiol. Rev. 4, 80-128.

Kaeckenbeeck, A., Thomas, J., 1960. A propos des sérotypes colibacillaires dans la diarrhée des veaux. Détermination des antigènes somatiques (O). Ann. Med. Vet. 104, 232-239.

Lalioui, L., Jouve, M., Gounon, P., Le Bouguenec, C., 1999. Molecular cloning and characterisation of the afa-7 and afa-8 gene clusters encoding afimbrial adhesins in Escherichia coli strains associated with diarrhea or septicemia in calves. Infect. Immunol. 67, 5048-5059.

Le Bouguenec, C., Archambeau, M., Labigne, A., 1992. Rapid and specific detection of the pap, afa and sfa adhesin-encoding operons in uropathogenic Escherichia coli strains by polymerase chain reaction. J. Clin. Microbiol. 30, 1189-1193.

Le Bouguenec, C., Bertin, Y., 1999. AFA and F17 adhesins produced by pathogenic Escherichia coli strains in domestic animals. Vet. Res. 30, 317-342.

Lintermans, P.F., Pohl, P., Deboeck, F., Bertels, A., Schlicker, C., Vandekerckhove, J., Van Damme, J., Van Montagu, M., De Greve, H., 1988. Isolation and nucleotide sequence of the F17A gene encoding the structural protein of the F17 fimbriae in bovine enterotoxigenic Escherichia coli. Infect. Immunol. 56, 1475-1784.

Mainil, J., Bex, F., Jacquemin, E., Pohl, P., Couturier, M., Kaeckenbeeck, A., 1990. Prevalence of four enterotoxin (StaP, StaH, STb, and LT) and four adhesin subunit (K99, K88, 987P, and F41) genes among Escherichia coli isolates from cattle. Am. J. Vet. Res. 51, 187-190.

Mainil, J., Hérault, F., Oswald, E., 1997. Presence of pap-, sfa-, and afa-related sequences in necrotoxigenic Escherichia coli isolates from cattle: evidence for new variants of the AFA family. Can. J. Vet. Res. 61, 193-199.

Mainil, J., Jacquemin, E., Pohl, P., Fairbrother, J.M., Ansuini, A., Le Bouguenec, C., Ball, H., De Rycke, J., Oswald, E., 1999. Comparison of necrotoxigenic Escherichia coli isolates from farm animals and from humans. Vet. Microbiol. 70, 123-135.

Mainil, J., Gérardin, J., Jacquemin, E., 2000. Identification of the F17 fimbrial subunit- and adhesin-encoding $(f 17 A$ and $f 17 G)$ gene variants in necrotoxigenic Escherichia coli from cattle, pigs and humans, pigs and humans. Vet. Microbiol. 73, 327-335.

Orden, J., Ruiz Santa Quiteiria, J., Cid, D., Garcia, S., de la Fuente, R., 1999. Prevalence and characteristics of necrotoxigenic Escherichia coli (NTEC) strains isolated from diarrhoeic dairy calves. Vet. Microbiol. 66, $265-273$.

Oswald, E., De Rycke, J., Guillot, J.-F., Boivin, R., 1989. Cytotoxic effect of multinucleation in HeLa cell cultures associated with the presence of Vir plasmid in Escherichia coli strains. FEMS Microbiol. Lett. 58, 95-100.

Oswald, E., De Rycke, J., Lintermans, P., Van Muylen, K., Mainil, J., Daube, G., Pohl, P., 1991. Virulence factors associated with cytotoxic necrotising factor type 2 in bovine diarrheic and septicemic strains of Escherichia coli. J. Clin. Microbiol. 29, 2522-2527.

Oswald, E., Sugai, M., Labigne, A., Wu, H., Fiorentini, C., Boquet, P., O’Brien, A., 1994a. Cytotoxic necrotising factor type 2 produced by virulent Escherichia coli modifies the small GTP-binding proteins Rho involved in assembly of actin stress fibers. Proc. Natl. Acad. Sci. 91, 3814-3818.

Oswald, E., Pohl, P., Jacquemin, E., Lintermans, P., Van Muylens, K., O’Brien, A.D., Mainil, J., 1994b. Specific DNA probes to detect Escherichia coli strains producing cytotoxic necrotising factor type1 or type 2. J. Med. Microbiol. 40, 428-434.

Pérès, S., Marchès, O., Daigle, F., Nougayrède, J.-P., Hérault, F., Tasca, C., De Rycke, J., Oswald, E., 1997. A new cytolethal distending toxin (CDT) from Escherichia coli producing CNF2 blocks HeLa cell division in G2/M phase. Mol. Microbiol. 24, 1095-1107. 
Pohl, P., Imberechts, H., Marin, M., Schlicker, C., Stockmans, F., 1997. Prévalence des gènes codant pour les cytotoxines nécrosantes (CNF1 et CNF2) chez des Escherichia coli isolées de bovins malades ou asymptomatiques. Ann. Med. Vet. 141, 161-164.

Schoenaers, F., Kaeckenbeeck, A., 1973. Contribution à l'étude de l'étiologie de la colibacillose intestinale du veau nouveau-né. Ann. Res. Vet. 4, 175-180.

Smith, H.W., 1974. A search for transmissible pathogenic characters in invasive strains of Escherichia coli: the discovery of a plasmid-controlled lethal character closely associated or identified with colicin V. J. Genet. Microbiol. 83, 95-111. 